\title{
Efficient removal of hexavalent chromium from aqueous solutions using autohydrolyzed Scots Pine (Pinus Sylvestris) sawdust as adsorbent
}

\author{
D. Sidiras • D. Politi · F. Batzias • N. Boukos
}

Received: 3 February 2012/Revised: 24 September 2012/Accepted: 22 January 2013/Published online: 16 March 2013

(C) Islamic Azad University (IAU) 2013

\begin{abstract}
In this work, a low-cost lignocellulosic adsorbent with high biosorption capacity is proposed, suitable for the efficient removal of hexavalent chromium from water and wastewater media. The adsorbent was produced by autohydrolyzing Scots Pine (Pinus Sylvestris) sawdust. The effect of the autohydrolysis conditions, i.e., pretreatment time and temperature, on hexavalent chromium biosorption was investigated using energy-dispersive X-ray spectroscopy (EDS) and UV-visible spectrophotometry. The Freundlich, Langmuir, Sips, Radke-Prausnitz, Modified Radke-Prausnitz, Tóth, UNILAN, Temkin and DubininRadushkevich adsorption capacities and the rate constant values for pseudo-first- and pseudo-second-order kinetics indicated that the autohydrolyzed material exhibits significantly enhanced hexavalent chromium adsorption properties comparing with the untreated sawdust. The Freundlich's adsorption capacity $K_{\mathrm{F}}$ increased from 2.276 to 8.928 (mg $\left.\mathrm{g}^{-1}\right)\left(\mathrm{L} \mathrm{mg}^{-1}\right)^{1 / n}$, and the amount of hexavalent chromium adsorbed at saturation (Langmuir constant $q_{\mathrm{m}}$ ) increased from 87.4 to $345.9 \mathrm{mg} \mathrm{g}^{-1}$, indicating that autohydrolysis treatment at $240{ }^{\circ} \mathrm{C}$ for $50 \mathrm{~min}$ optimizes the adsorption behavior of the lignocellulosic material.
\end{abstract}

Keywords Biomass - Biosorption · Heavy metals · Lignocellulosic $\cdot$ Modification

D. Sidiras $(\varangle) \cdot$ D. Politi · F. Batzias

Laboratory of Simulation of Industrial Processes, Department of Industrial Management and Technology, University of Piraeus, 80 Karaoli and Dimitriou, 18534 Piraeus, Greece e-mail: sidiras@unipi.gr

URL: http://www.tex.unipi.gr/en/faculty/sidiras/main.htm

N. Boukos

Institute of Material Science, National Centre for Scientific Research "Demokritos", Agia Paraskevi, 15310 Athens, Greece

\section{Introduction}

Adsorption is by far the most versatile and widely used method for wastewater metal removal and decoloration. Activated carbon has been commonly used as an adsorbent for the municipal and industrial wastewater cleaning, but its high cost has prompted research on suitable low-cost substitutes, currently focusing on wasted lignocellulosic materials; in fact, wood sawdust and agricultural residues have been extensively investigated as adsorbents (Bansal et al. 2009; Gupta and Babu 2009; Gupta et al. 2009; Mohan et al. 2011).

The presence of heavy metals in the aquatic environment has been of great concern because discharges increase their toxicity and other adverse effects on the receiving waters. Biomagnification, an increase in trace metal concentration through at least two trophic levels in a food chain, elevates trace metal concentrations in higher trophic group organisms, posing a threat to the organisms themselves or to human consumers (Barwick and Maher 2003). Hexavalent chromium exhibits a well-established toxicity and it is considered a priority pollutant. Especially for Greece, the issue of $\mathrm{Cr}(\mathrm{VI})$ water contamination has recently received much attention owing to its impact on Assopos basin, a proclaimed processed industrial waste receiver that is also used for irrigation (Economou-Eliopoulos et al. 2011). Industrial sources of $\mathrm{Cr}(\mathrm{VI})$ include leather tanning, cooling tower blowdown, plating, electroplating, anodizing baths, rinse waters, etc. The sorption capacities of commercial developed carbons and low-cost alternative adsorbents for tri- and hexavalent chromium remediation have been studied by numerous researchers and the mechanisms of adsorption on various adsorbents have been established (Mohan et al. 2011). Mostly untreated and pretreated lignocellulosic industrial byproducts and agricultural residues have been employed as adsorbents for hexavalent chromium removal 
from water. These materials include sawdust (Baral et al. 2006; Aliabadi et al. 2006; Vinodhini and Das 2010), coir pith (Sumathi et al. 2005), oil palm fiber (Isa et al. 2008), wheat straw carbon (Chand et al. 2009), barley straw carbon (Chand et al. 2009), leaf mould (Sharma and Forster, 1996), wheat bran (Nameni et al., 2008; Singh et al. 2009), cotton stalk peel (Xu et al. 2011), maize tassel (Zvinowanda et al. 2009), walnut shell (Pehlivan and Altun 2008), walnut hull (Wang et al. 2009), hazelnut shell (Pehlivan and Altun 2008), almond shell (Pehlivan and Altun 2008), rice bran (Oliveira et al. 2005), rice husk (Sumathi et al. 2005), soybean hulls (Marshall and Wartelle 2004), eucalyptus bark (Sarin and Pant 2006), Tamarindus indica seeds (Agarwal et al. 2006), tea factory waste (Vinodhini and Das 2010), spent mushroom modified by cationic surfactant (Jing et al. 2011), and olive stone (Blázquez et al. 2009). Furthermore, since lignocellulosic materials are used in the bioethanol industry as source of sugars (Mosier et al. 2005), the process solid residue can be, also, implemented as adsorbent.

Autohydrolysis is frequently used to increase the efficiency of lignocellulosics' enzymatic hydrolysis to sugars (Nabarlatz et al. 2007). Many industrial byproducts and agricultural residues can be autohydrolyzed for the production of sugars (Sidiras et al. 2011a), while the autohydrolysis solid residue can be efficiently used as dye adsorbent (Sidiras et al. 2011b).

In this work, a low-cost adsorbent with high capacity is presented, suitable for the efficient removal of hexavalent chromium from water and wastewater. The adsorbent was produced from Scots Pine (Pinus Sylvestris) sawdust autohydrolysis. In an earlier work (Sidiras et al. 2011b), the effect of pretreatment on the microstructure and the crystallinity of pine sawdust was investigated by means of SEM, FTIR, $\mathrm{XRD}$, and BET; in this work, energy-dispersive X-ray spectroscopy (EDS) was further used to measure the percentage of the chromium at the solid phase of the adsorption system, i.e., at the untreated and pretreated sawdust before and after adsorption. The batch adsorption kinetics of $\mathrm{Cr}$ (VI) was used to estimate and compare the adsorption capacity of the untreated and pretreated pine sawdust. The study was done at (i) Laboratory of Simulation of Industrial Processes, Department of Industrial Management and Technology, University of Piraeus and (ii) Institute of Material Science, National Centre for Scientific Research "Demokritos", Athens, Greece from January 2011 to January 2012.

\section{Materials and methods}

Material development

The Scots Pine (Pinus Sylvestris) sawdust was obtained from a local furniture manufacturing company. The
Table 1 Composition of the autohydrolyzed pine sawdust as a function of the autohydrolysis time at $160-240{ }^{\circ} \mathrm{C}$

\begin{tabular}{|c|c|c|c|}
\hline Time, $t_{a i}(\min )$ & $160{ }^{\circ} \mathrm{C}$ & $200{ }^{\circ} \mathrm{C}$ & $240^{\circ} \mathrm{C}$ \\
\hline \multicolumn{4}{|c|}{ Cellulose $(\% \mathrm{w} / \mathrm{w})$} \\
\hline- & 40.1 & 40.1 & 40.1 \\
\hline 0 & 42.6 & 48.6 & 44.2 \\
\hline 10 & 44.2 & 49.1 & 44.1 \\
\hline 20 & 45.4 & 49.2 & 33.5 \\
\hline 30 & 47.3 & 49.5 & 30.1 \\
\hline 40 & 46.9 & 49.2 & 22.8 \\
\hline 50 & 47.8 & 50.3 & 18.9 \\
\hline \multicolumn{4}{|c|}{ Hemicelluloses $(\% \mathrm{w} / \mathrm{w})$} \\
\hline- & 28.5 & 28.5 & 28.5 \\
\hline 0 & 28.2 & 10.7 & 0 \\
\hline 10 & 23.9 & 5.9 & 0 \\
\hline 20 & 19.1 & 2.3 & 0 \\
\hline 30 & 17.2 & 1.0 & 0 \\
\hline 40 & 15.3 & 0.3 & 0 \\
\hline 50 & 14.6 & 0.2 & 0 \\
\hline \multicolumn{4}{|l|}{ Lignin $(\% \mathrm{w} / \mathrm{w})$} \\
\hline- & 27.7 & 27.7 & 27.7 \\
\hline 0 & 29.9 & 34.9 & 42.4 \\
\hline 10 & 31.4 & 36.6 & 47.0 \\
\hline 20 & 31.9 & 37.8 & 49.6 \\
\hline 30 & 33.1 & 39.1 & 51.4 \\
\hline 40 & 33.0 & 39.8 & 60.8 \\
\hline 50 & 33.2 & 40.6 & 62.4 \\
\hline
\end{tabular}

moisture content of the material was $8.7 \% \mathrm{w} / \mathrm{w}$; the fraction with particle sizes between 0.2 and $1 \mathrm{~mm}$ was used. The composition of the raw material is presented in Table 1 . The autohydrolysis pretreatment was performed in a $3.75 \mathrm{~L}$ batch reactor PARR 4843. The isothermal hydrolysis times were 0,10, 20, 30, 40, and $50 \mathrm{~min}$ (not including the non-isothermal preheating and the cooling time-periods); the liquid-to-solid ratio was 10:1; the liquidphase volume was $2,000 \mathrm{~mL}$, the solid material dose was $200 \mathrm{~g}$, and the stirring speed $150 \mathrm{rpm}$. The temperature values were 160,200 , and $240{ }^{\circ} \mathrm{C}$, reached after 42,62 , and 80 min preheating period values, respectively.

Adsorption isotherm studies

Adsorption isotherms were derived from batch experiments. Following the batch procedure, accurately weighed quantities of adsorbent were transferred into $0.8 \mathrm{~L}$ bottles, where $0.5 \mathrm{~L}$ of adsorbate solution was added. The adsorbent weight varied from $0.5 \mathrm{~g}$ to $4 \mathrm{~g}$ (i.e. $m / V=1-8 \mathrm{~g}$ $\mathrm{L}^{-1}$ ), the temperature was $23{ }^{\circ} \mathrm{C}$, and the initial $\mathrm{Cr}(\mathrm{VI})$ concentration varied from $15 \mathrm{mg} \mathrm{L}^{-1}$ to $700 \mathrm{mg} \mathrm{L}^{-1}$; 
$\mathrm{K}_{2} \mathrm{Cr}_{2} \mathrm{O}_{7}$ was used as $\mathrm{Cr}(\mathrm{VI})$ source. The $\mathrm{pH}$ of the solutions was adjusted to 2.0 using dilute $\mathrm{H}_{2} \mathrm{SO}_{4}$. The bottles were sealed and mechanically tumbled for a period of 7 days. Isotherms were studied for $4 \mathrm{~h}$ to 14 days and the equilibrium achieved at 7 days. The resulting solution concentrations were determined and the equilibrium data from each bottle provided one point on the adsorption isotherm plots.

\section{Kinetic studies}

Adsorption rate batch experiments were conducted in a $2 \mathrm{~L}$ completely mixed glass reactor fitted with a twisted blade-type stirrer, operating at $600 \mathrm{rpm}$ for keeping the lignocellulosic material in suspension. Stirring speed 100-600 rpm was studied and $600 \mathrm{rpm}$ was chosen to achieve kinetic parameter values, not affected by the stirring speed. This was comparable to the literature findings (Baral et al. 2008). The reactor, containing $1 \mathrm{~L}$ aqueous $\mathrm{Cr}(\mathrm{VI})$ solution, was placed into a water bath to keep temperature constant at the desired level $\left(23^{\circ} \mathrm{C}\right)$. The sorbent weight varied from $1 \mathrm{~g}$ to $8 \mathrm{~g}$ sawdust (i.e. $m / V=$ 1-8 $\left.\mathrm{g} \mathrm{L}^{-1}\right)$, and the initial $\mathrm{Cr}(\mathrm{VI})$ concentration varied from 1.6 to $7.7 \mathrm{mg} \mathrm{L}^{-1}$. The effect of contact time ( $\mathrm{t}$ in $\mathrm{min}$ ), adsorbent dose (sawdust in g), and initial concentrations of adsorbate $\left(\mathrm{mg} \mathrm{L}^{-1} \mathrm{Cr}(\mathrm{VI})\right)$ on the uptake of $\mathrm{Cr}(\mathrm{VI})$ were studied in triplicate batch experiments. The $\mathrm{pH}$ effect was also studied in the range of 1.2-3.4; the $\mathrm{pH}$ of the solutions was adjusted using $\mathrm{H}_{2} \mathrm{SO}_{4}$ solution according to the guidelines of numerous researchers (Dean and Tobin 1999; Isa et al. 2008); the $\mathrm{H}_{2} \mathrm{SO}_{4}$ solution was $3.6 \mathrm{~N}$ with maximum volume $5 \mathrm{~mL}$ per $1 \mathrm{~L}$ of $\mathrm{Cr}(\mathrm{VI})$ solution. The predominant species at $\mathrm{pH} 2$ is expected to be $\mathrm{HCrO}_{4}{ }^{-}$(Dean and Tobin 1999) while other species of chromium $\left(\mathrm{Cr}_{2} \mathrm{O}_{7}{ }^{2-}, \mathrm{Cr}_{3} \mathrm{O}_{10}{ }^{2-}, \mathrm{Cr}_{4} \mathrm{O}_{13}{ }^{2-}\right)$ coexist in the acid media (Blázquez et al. 2009). Desorption experiments were carried out using $1 \mathrm{~L}$ pure water per $4 \mathrm{~g}$ of $\mathrm{Cr}(\mathrm{VI})$ saturated sawdust; the $\mathrm{pH}$ was 7.8.

\section{Analytical techniques}

The Saeman et al. (1945) technique was used for the quantitative saccharification of the original lignocellulosic material and the autohydrolysis reaction solid residues. The filtrates from the quantitative saccharification were analyzed for glucose, xylose, and arabinose using high-performance liquid chromatography (HPLC, Agilent 1200) with Aminex HPX-87H Column, refractive index detector, and $5 \mathrm{mM} \mathrm{H}_{2} \mathrm{SO}_{4}$ in water as the mobile phase. Cellulose was estimated as glucan and hemicelluloses were estimated as xylan and arabinan. Finally, the acid-insoluble lignin (Klason lignin) was determined according to the Tappi Standards (1997) T222 om-88 method.
The study of pine sawdust samples by scanning electron microscopy (SEM) was conducted at the Institute of Materials Science of the National Center for Scientific Research 'Demokritos' using an FEI INSPECT SEM equipped with an EDAX super ultra thin window analyzer for energy-dispersive X-ray spectroscopy (EDS). EDAX was used for the direct measurement of the percentage of the chromium at the untreated and pretreated sawdust before and after adsorption.

Hexavalent chromium was determined by the 1,5-Diphenylcarbohydrazide method using a single dry powder formulation. This reagent contains an acidic buffer combined with 1,5-Diphenylcarbohydrazide, which reacts to give a purple color when hexavalent chromium is present. Test results are measured at $540 \mathrm{~nm}$. A HACH DR4000U UV-visible spectrophotometer was used. The method applied is suggested under the code 8023 in the Procedures Manual by the instrument manufacturer (http://www.hach.com/asset-get.downloaden.jsa?id=7639983704). This method is USEPA accepted for reporting for wastewater analysis; it is also equivalent to (i) the Standard Method $3500 \mathrm{Cr}$ B in "Standard Methods for the Examination of Water and Wastewater" suggested by American Public Health Association (APHA), American Water Works Association (AWWA) and Water Environment Federation (WEF), and (ii) to USGS method 1-1230-85 for wastewater. The maximum concentration that can be measured with this method is $0.7 \mathrm{mg} \mathrm{L}^{-1}$; dilution factor was 10-1,000. Each sample was measured in triplicate to eliminate the dilution error. Finally, $\mathrm{pH}$ measurements were made using a digital $\mathrm{pH}$ meter, MultiLab model 540 .

\section{Results and discussion}

\section{Autohydrolysis}

Cellulose fractions are hydrolyzed to water-soluble cellulo-oligosaccharides and glucose, hemicelluloses are hydrolyzed to xylo-oligosaccharides and xylose, and acidinsoluble lignin fraction is not significantly affected by autohydrolysis (Mosier et al. 2005; Sidiras et al. 2011a). The composition of the autohydrolyzed pine sawdust (dry weight of product $\% \mathrm{w} / \mathrm{w}$ of the original dry material) is presented in Table 1 , as a function of autohydrolysis time $\left(t_{a i}\right.$ in min). The hemicelluloses percentage of the autohydrolyzed pine sawdust was significantly decreased by autohydrolysis intensification. The cellulose percentage of the pretreated sawdust reached a maximum of $50.3 \% \mathrm{w} / \mathrm{w}$ at $200{ }^{\circ} \mathrm{C}$ for $50 \mathrm{~min}$. The lignin percentage of the solid residue increased up to $62.4 \% \mathrm{w} / \mathrm{w}$ at $240{ }^{\circ} \mathrm{C}$ for $50 \mathrm{~min}$. Maximum lignin $\% \mathrm{w} / \mathrm{w}$ was the desirable property of the autohydrolyzed final product to achieve maximum adsorption capacity $q_{\mathrm{m}}$. An 
Table 2 Estimated parameter values for the alternative isotherm models

$\mathrm{K}_{\mathrm{L}}\left(\mathrm{L} \mathrm{mg}^{-1}\right) \quad q_{\mathrm{m}}\left(\mathrm{mg} \mathrm{g}^{-1}\right)$ or $\mathrm{K}_{\mathrm{F}}\left[\left(\mathrm{mg} \mathrm{g}^{-1}\right) \quad n \quad\right.$ SEE

$\left.\left(\mathrm{L} \mathrm{mg}^{-1}\right)^{1 / n}\right]$

\begin{tabular}{|c|c|c|c|c|}
\hline \multicolumn{5}{|l|}{ Untreated sawdust } \\
\hline Freundlich & & $2.276(2.024-2.527)$ & $1.945(1.879-2.024)$ & 2.524 \\
\hline Langmuir & $0.00348(0.00204-0.00592)$ & $87.4(66.4-108.5)$ & & 5.430 \\
\hline Sips & $9.9 \times 10^{-8}\left(7.3 \times 10^{-8}-12.9 \times 10^{-8}\right)$ & $9,132(7,810-10,458)$ & $1.945(1.889-1.996)$ & 2.674 \\
\hline Radke-Prausnitz & $89,617(66,210-116,560)$ & $0.00651(0.00557-0.00745)$ & $2.057(2.019-2.091)$ & 2.662 \\
\hline $\begin{array}{l}\text { Modified Radke- } \\
\text { Prausnitz }\end{array}$ & $\begin{array}{l}1.32 \times 10^{-5}\left(0.671 \times 10^{-5}-\right. \\
\left.2.74 \times 10^{-5}\right)\end{array}$ & $15,897(10,288-21,534)$ & $0.0111(0.0060-0.0247)$ & 6.429 \\
\hline Tóth & $0.761(0.749-0.771)$ & $\begin{array}{l}1.77 \times 10^{8}\left(1.50 \times 10^{8}-\right. \\
\left.2.05 \times 10^{8}\right)\end{array}$ & $0.0459(0.0455-0.0463)$ & 2.850 \\
\hline UNILAN & $\begin{array}{l}1.83 \times 10^{-9}\left(0.906 \times 10^{-9}-\right. \\
\left.2.81 \times 10^{-9}\right)\end{array}$ & $15,896(8,015-23,803)$ & $11.507(10.733-11.977)$ & 8.887 \\
\hline Temkin & $0.6529(0.1072-3.979)$ & $7.579(4.034-11.124)$ & & 10.206 \\
\hline Dubinin-Radushkevich & & $46.80(23.85-69.75)$ & $3,408(73-73,446)$ & 10.651 \\
\hline \multicolumn{5}{|c|}{ Autohydrolyzed sawdust (at $200{ }^{\circ} \mathrm{C}$ for $50 \mathrm{~min}$ ) } \\
\hline Freundlich & & $9.227(8.100-10.354)$ & $2.077(1.995-2.179)$ & 9.618 \\
\hline Langmuir & $0.00702(0.00370-0.0140)$ & $224.1(175.3-273.0)$ & & 17.034 \\
\hline Sips & $8.4 \times 10^{-8}\left(5.8 \times 10^{-8}-11.5 \times 10^{-8}\right)$ & $23,649(19,878-27,435)$ & $2.077(2.008-2.140)$ & 10.164 \\
\hline Radke-Prausnitz & $351.48(244.39-479.02)$ & $0.566(0.476-0.657)$ & $1.919(1.865-1.967)$ & 10.195 \\
\hline $\begin{array}{l}\text { Modified Radke- } \\
\text { Prausnitz }\end{array}$ & $\begin{array}{l}3.49 \times 10^{-5}\left(1.60 \times 10^{-5}-\right. \\
\left.9.55 \times 10^{-5}\right)\end{array}$ & $23,639(15,225-32,050)$ & $0.0213(0.0126-0.0388)$ & 22.344 \\
\hline Tóth & $0.850(0.833-0.864)$ & $\begin{array}{l}3.12 \times 10^{7}\left(2.60 \times 10^{7}-\right. \\
\left.\quad 3.63 \times 10^{7}\right)\end{array}$ & $0.0513(0.0507-0.0518)$ & 10.503 \\
\hline UNILAN & $\begin{array}{l}4.8 \times 10^{-10}\left(2.4 \times 10^{-10}-\right. \\
\left.\quad 7.7 \times 10^{-10}\right)\end{array}$ & $23,634(12,417-35,649)$ & $13.918(13.171-14.431)$ & 29.914 \\
\hline Temkin & $0.8858(0.1303-6.025)$ & $23.97(13.10-34.83)$ & & 34.235 \\
\hline Dubinin-Radushkevich & & $152.18(90.79-213.56)$ & $1,473(98-46,996)$ & 30.744 \\
\hline
\end{tabular}

increasing of (62.4-27.7)/27.7 $=125 \%$ was achieved for lignin (see Table 1). As a side effect, a decrease of $(40.1-18.9) / 40.1=53.4 \%$ for cellulose and $100 \%$ for hemicelluloses was observed. This resulted also in the improvement of the adsorption capacity $q_{\mathrm{m}}$ (see Table 2 ).

The effect of the autohydrolysis conditions, i.e., time and temperature, on hexavalent chromium quantity adsorbed by the sawdust was investigated using energy-dispersive X-ray spectroscopy (EDS), and the results are presented in Fig. 1; the adsorbed $\mathrm{Cr}(\mathrm{VI})$ was found to be $5 \mathrm{mg} \mathrm{g}^{-1}$ for the untreated sawdust and $16 \mathrm{mg} \mathrm{g}^{-1}$ for the pretreated material (autohydrolysis $200{ }^{\circ} \mathrm{C}, 50 \mathrm{~min}$ ). When measured spectrophotometrically (indirectly by $\mathrm{Cr}(\mathrm{VI})$ decline in solution), the adsorbed $\mathrm{Cr}(\mathrm{VI})$ was found to be $12 \mathrm{mg} \mathrm{g}^{-1}$ for the untreated sawdust and $32 \mathrm{mg} \mathrm{g}^{-1}$ for the pretreated material. The higher values given by the spectrophotometer method are due to the presence of $\mathrm{Cr}$ (III) in the solution that cannot be discriminated by the $\mathrm{Cr}(\mathrm{VI}) \mathrm{HACH}$ method. Notwithstanding, the sawdust adsorptivity improved approximately three times according to both measurement methods. Furthermore, Park et al. (2005), reported that $\mathrm{Cr}(\mathrm{VI})$ removal occurred partly through reduction as well as anionic adsorption. This reduction could only have taken place under strong acidic conditions. $\mathrm{Cr}(\mathrm{VI})$ is easily or spontaneously reduced to $\mathrm{Cr}$ (III) when $\mathrm{Cr}$ (VI) comes in contact with sawdust in acidic medium. Moreover, reduction of $\mathrm{Cr}(\mathrm{VI})$ to $\mathrm{Cr}(\mathrm{III})$ is dependent on the nature of the adsorbent, the $\mathrm{Cr}(\mathrm{VI})$ concentration, and the time.

Adsorption isotherms

\section{Isotherm models' equations}

Seven isotherm models were applied to fit the experimental results. The Freundlich (Freundlich 1906) isotherm is given by the following equation:

$q=K_{\mathrm{F}} \cdot\left(C_{\mathrm{e}}\right)^{\frac{1}{n}}$

where $q$ is the amount adsorbed per unit mass of the adsorbent ( $\left.\mathrm{mg} \mathrm{g}^{-1}\right), C_{\mathrm{e}}$ is the equilibrium concentration of the adsorbate $\left(\mathrm{mg} \mathrm{L}^{-1}\right)$, and $K_{\mathrm{F}}, n$ are the Freundlich constants related to adsorption capacity and intensity, respectively. Eq. (1) in logarithmic form gives 
Fig. 1 EDS spectra for untreated $(\mathbf{a}, \mathbf{b})$ and autohydrolyzed at $200{ }^{\circ} \mathrm{C}$ for $50 \mathrm{~min}(\mathbf{c}, \mathbf{d})$ pine sawdust, before $(\mathbf{a}, \mathbf{c})$ and after (b, d) $\mathrm{Cr}(\mathrm{VI})$ adsorption. Conditions: initial $\mathrm{Cr}(\mathrm{VI})$ concentration $700 \mathrm{mg} / \mathrm{L}$, sawdust weight $4 \mathrm{~g}$ (i.e. $m / V=4 \mathrm{~g} / \mathrm{L}$ ), $\mathrm{pH} 2$, adsorption temperature $23{ }^{\circ} \mathrm{C}$, and adsorption time $190 \mathrm{~min}$
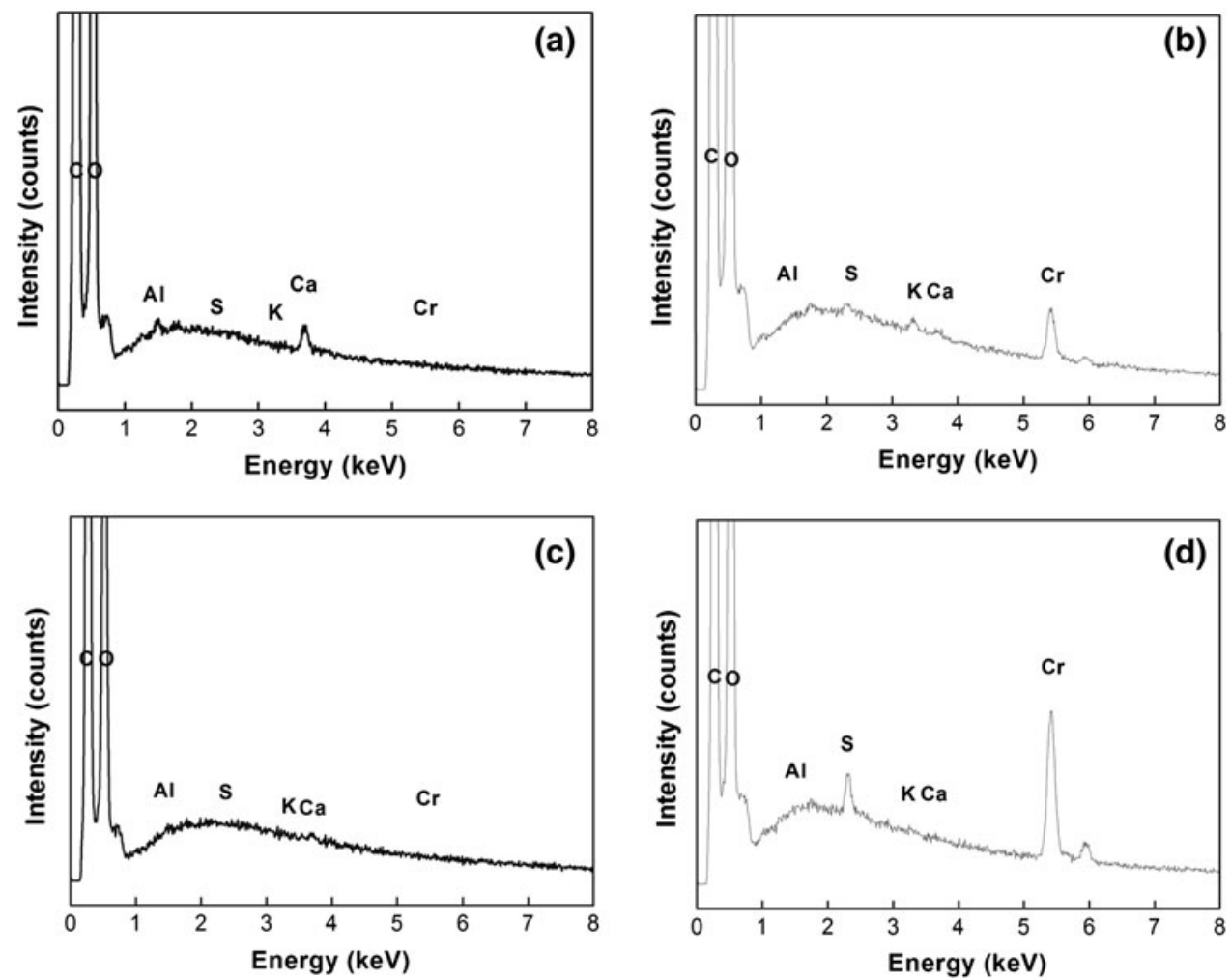

$\log q=\log K_{\mathrm{F}}+\frac{1}{n} \log C_{\mathrm{e}}$

$K_{\mathrm{F}}$ and $n$ were estimated by non-linear regression analysis (NLRA) from the experimental adsorption data obtained at $23{ }^{\circ} \mathrm{C}$ for $\mathrm{Cr}(\mathrm{VI})$, while the values of $K_{\mathrm{F}}$ and $n$ estimated by linear least squares regression through Eq. (2) were used as initial values for starting the algorithmic procedure of NLRA. From the environmental point of view, parameter $K_{\mathrm{F}}$ is the most important one representing the adsorption capacity of the materials produced herein for low $\mathrm{Cr}(\mathrm{VI})$ concentration $C_{\mathrm{e}}=1 \mathrm{mg} \mathrm{L}^{-1}$.

The Langmuir isotherm (Langmuir 1916) is given by the following equation:

$q=\frac{K_{\mathrm{L}} q_{\mathrm{m}} C_{\mathrm{e}}}{1+K_{\mathrm{L}} C_{\mathrm{e}}}$

or

$\frac{1}{q}=\left(\frac{1}{q_{\mathrm{m}}}\right)+\left(\frac{1}{K_{\mathrm{L}} \cdot q_{\mathrm{m}}}\right) \cdot\left(\frac{1}{C_{\mathrm{e}}}\right)$

where $K_{\mathrm{L}}$ is the Langmuir constant related to the energy of adsorption ( $\mathrm{L} \mathrm{mg}^{-1}$ ) and $q_{\mathrm{m}}$ the amount of $\mathrm{Cr}(\mathrm{VI})$ adsorbed ( $\mathrm{mg} \mathrm{g}^{-1}$ ) when saturation is attained. The parameters $K_{\mathrm{L}}$ and $q_{\mathrm{m}}$ can be obtained either by plotting $1 / q$ versus $1 / C_{\mathrm{e}}$ or by non-linear regression analysis. From the technical point of view, parameter $q_{\mathrm{m}}$ is the most important parameter representing the maximum adsorption capacity of the materials produced herein.

The characteristics of the Langmuir isotherm can be described by a dimensionless constant, called 'equilibrium parameter' or 'separation factor' $R_{\mathrm{L}}$ :

$R_{\mathrm{L}}=\frac{1}{1+K_{\mathrm{L}} \cdot C_{0}}$

where $C_{0}$ is the initial $\mathrm{Cr}(\mathrm{VI})$ concentration $\left(\mathrm{mg} \mathrm{L}^{-1}\right)$.

The Sips (Langmuir-Freundlich) (Sips 1948) isotherm equation is

$q=\frac{q_{\mathrm{m}} \cdot\left(K_{\mathrm{L}} \cdot C_{\mathrm{e}}\right)^{1 / n}}{1+\left(K_{\mathrm{L}} \cdot C_{\mathrm{e}}\right)^{1 / n}}$ or

$\frac{1}{q}=\left(\frac{1}{q_{\mathrm{m}}}\right)+\left(\frac{1}{K_{\mathrm{L}}^{1 / n} \cdot q_{\mathrm{m}}}\right) \cdot\left(\frac{1}{C_{\mathrm{e}}}\right)^{1 / n}$

where $K_{\mathrm{L}}$ and $q_{\mathrm{m}}$ is the Langmuir constants, and $n$ the Freundlich constant.

The Radke-Prausnitz (Radke and Prausnitz 1972; Chern and $\mathrm{Wu} 2001$ ) isotherm equation is

$q=\frac{K_{\mathrm{L}} \cdot q_{\mathrm{m}} \cdot C_{\mathrm{e}}}{1+K_{\mathrm{L}} \cdot C_{\mathrm{e}}^{1 / n}}$

The Modified Radke-Prausnitz (Chern and Wu 2001) isotherm equation is 
$q=\frac{K_{\mathrm{L}} \cdot q_{\mathrm{m}} \cdot C_{\mathrm{e}}}{\left(1+K_{\mathrm{L}} \cdot C_{\mathrm{e}}\right)^{1 / n}}$

The Tóth (Toth 2000) isotherm equation is

$q=\frac{q_{\mathrm{m}} \cdot C_{\mathrm{e}}}{\left(1 / K_{\mathrm{L}}+C_{\mathrm{e}}^{n}\right)^{1 / n}}$

The UNILAN (Chern and Wu 2001) isotherm equation is

$q=\frac{q_{\mathrm{m}}}{2 s} \ln \left(\frac{1+K_{\mathrm{L}} \cdot C_{\mathrm{e}} \cdot e^{s}}{1+K_{\mathrm{L}} \cdot C_{\mathrm{e}} \cdot e^{-s}}\right)$

where $s$ is a new constant.

The Temkin isotherm model (Temkin and Pyzhev 1940) is

$q=\frac{R T}{b_{\mathrm{T}}} \ln \left(A_{\mathrm{T}} C_{\mathrm{e}}\right)$ or $q=B_{\mathrm{T}} \ln \left(A_{\mathrm{T}} C_{\mathrm{e}}\right)$ or $q=q_{\mathrm{m}} \ln \left(K_{\mathrm{L}} C_{\mathrm{e}}\right)$

where $R=0.008314 \mathrm{~kJ} \mathrm{~mol}^{-1} \mathrm{~K}^{-1}, T$ is the adsorption temperature in $\mathrm{K}, K_{L}=A_{T}$ in $\mathrm{L} \mathrm{mg}^{-1}$ and $q_{\mathrm{m}}=B_{\mathrm{T}}=R T$ / $b_{\mathrm{T}}$ in $\mathrm{mg} \mathrm{g}^{-1}$. In linearized form Eq. (11) is as follows:

$q=a_{\mathrm{T}}+q_{\mathrm{m}} \ln \left(C_{\mathrm{e}}\right)$

where $a_{\mathrm{T}}=q_{\mathrm{m}} \ln \left(K_{L}\right)$.

The Dubinin-Radushkevich (Dubinin and Radushkevich 1947) isotherm model is

$q=q_{\mathrm{D}} \exp \left\{-B_{\mathrm{D}}\left[R T \ln \left(1+\frac{1}{C_{\mathrm{e}}}\right)\right]^{2}\right\}$ or

$q=q_{\mathrm{D}} \exp \left\{-A_{\mathrm{D}}\left[\ln \left(1+\frac{1}{C_{\mathrm{e}}}\right)\right]^{2}\right\}$ or

$q=q_{\mathrm{m}} \exp \left\{-n\left[\ln \left(1+\frac{1}{C_{\mathrm{e}}}\right)\right]^{2}\right\}$

where $q_{\mathrm{m}}=q_{\mathrm{D}}$ in $\mathrm{mg} \mathrm{g}^{-1}$ and $n=A_{\mathrm{D}}=B_{\mathrm{D}} R^{2} T^{2}$ a dimensionless constant for $T=$ constant.

\section{Isotherm results and discussion}

Figure 2 presents, as an example, $\mathrm{Cr}(\mathrm{VI})$ adsorption isotherms for untreated and pretreated $\left(200{ }^{\circ} \mathrm{C}, 50 \mathrm{~min}\right)$ pine

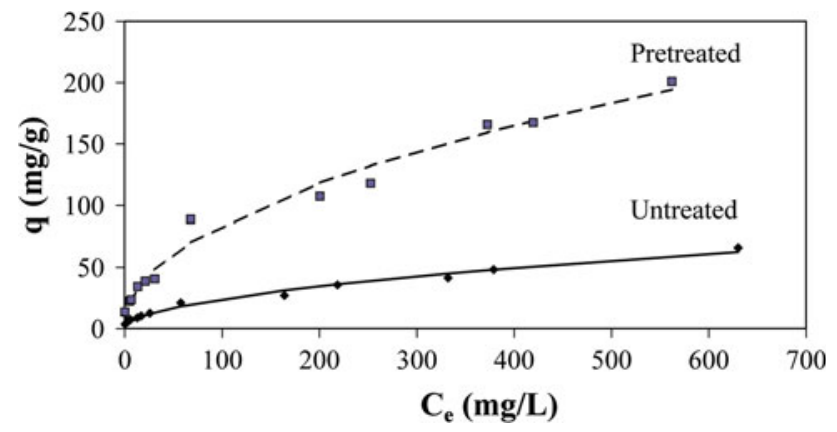

Fig. 2 Isotherms of untreated and autohydrolyzed at $240{ }^{\circ} \mathrm{C}$ for 50 min pine sawdust sawdust following the Freundlich model. The Freundlich parameter values are shown in Table 2; the confidence intervals of the isotherm model coefficients are also presented in this Table, for confidence level $95 \%$. The $K_{\mathrm{F}}$ values estimated for the autohydrolyzed samples were higher than those of the untreated material, while the $n$ values were similar for both materials. The $K_{\mathrm{F}}$ confidence intervals are not overlapping for confidence level $95 \%$. For example, $K_{\mathrm{F}}=2.276\left(\mathrm{mg} \mathrm{g}^{-1}\right)\left(\mathrm{L} \mathrm{mg}^{-1}\right)^{1 / n}$ with confidence interval $2.024-2.527\left(\mathrm{mg} \mathrm{g}^{-1}\right)\left(\mathrm{L} \mathrm{mg}^{-1}\right)^{1 / n}$ for untreated while $9.227\left(\mathrm{mg} \mathrm{g}^{-1}\right)\left(\mathrm{L} \mathrm{mg}^{-1}\right)^{1 / n}$ with confidence interval $8.100-10.354\left(\mathrm{mg} \mathrm{g}^{-1}\right)\left(\mathrm{L} \mathrm{mg}^{-1}\right)^{1 / n}$ for pretreated sawdust. Consequently, $2.527<8.100\left(\mathrm{mg} \mathrm{g}^{-1}\right)$ $\left.(\mathrm{L} \mathrm{mg})^{-1}\right)^{1 / n}$. The standard error of estimate (SEE) was calculated in each case by the following expression:

$\mathrm{SEE}=\sqrt{\sum_{i=1}^{n^{\prime}}\left(y_{i}-y_{i, \text { theor }}\right)^{2} /\left(n^{\prime}-p^{\prime}\right)}$

where $y_{i}$ is the experimental value of the depended variable, $y_{i, \text { theor }}$ is the theoretical or estimated value of the depended variable, $n^{\prime}$ is the number of the experimental measurements, and $p^{\prime}$ the number of parameters (the difference $n-p^{\prime}$ being the number of the degrees of freedom). The fitting of the Freundlich adsorption model to the experimental data was very satisfactory (see Table 2; Fig. 2). Moreover, the Freundlich constants $K_{\mathrm{F}}$ for the removal of $\mathrm{Cr}(\mathrm{VI})$ by adsorption on pine sawdust as affected by the autohydrolysis time $t_{\mathrm{a}}$ was found herein to follow the parabolic relation:

$K_{\mathrm{F}}=a_{2} t_{\mathrm{a}}^{2}+a_{1} t_{\mathrm{a}}+a_{0}$

where $a_{0}, a_{1}$, and $a_{2}$ are empirical parameters, depending on the autohydrolysis temperature, given in Table 3.

Moreover, Table 2 presents the Langmuir NLRA parameter values estimates for the data gathered in the present study. The values of $q_{\mathrm{m}}$ obtained for untreated pine sawdust were lower than the values for the pretreated samples; e.g., $q_{\mathrm{m}}=87.4 \mathrm{mg} \mathrm{g}^{-1}$ with confidence interval $66.4-108.5 \mathrm{mg} \mathrm{g}^{-1}$ for untreated while $224.1 \mathrm{mg} \mathrm{g}^{-1}$ with confidence interval $175.3-273.0 \mathrm{mg} \mathrm{g}^{-1}$ for pretreated sawdust. It is obvious that $108.5<175.3 \mathrm{mg} \mathrm{g}^{-1}$. The fitting of the Langmuir's adsorption model to the present data was also very satisfactory but to a lesser degree than that using the Freundlich model for both materials, as shown by the corresponding SEE-values given in Table 2 . The Langmuir constant $q_{\mathrm{m}}$ was similarly found to follow the same as in Eq. (15) parabolic relation (see Table 2):

$q_{\mathrm{m}}=a_{2} t_{\mathrm{a}}^{2}+a_{1} t_{\mathrm{a}}+a_{0}$

At the present work, the $R_{\mathrm{L}}$ values were found between 0 and 1 for all $\operatorname{Cr}(\mathrm{VI})$ concentrations $C_{0}$ and for all adsorbents studied. This fact indicates a favorable 
Table 3 Parameters of Eqs. (4) and (7) for the prediction of the Freundlich and Langmuir parameters as affected by the pine sawdust autohydrolysis time and temperature

\begin{tabular}{|c|c|c|c|c|}
\hline$T_{\theta a}\left({ }^{\circ} \mathrm{C}\right)$ & $a_{2}$ & $a_{1}$ & $a_{0}$ & $R^{2}$ \\
\hline \multicolumn{5}{|c|}{ The case of the Freundlich isotherm model } \\
\hline 160 & 0 & $0.0257 \pm 0.0038$ & $2.2404 \pm 0.2427$ & 0.9021 \\
\hline 200 & $-0.00043 \pm 0.0009$ & $0.1082 \pm 0.0100$ & $2.2943 \pm 0.2776$ & 0.9907 \\
\hline 240 & $-0.00072 \pm 0.00005$ & $0.1459 \pm 0.0065$ & $2.2656 \pm 0.2004$ & 0.9964 \\
\hline \multicolumn{5}{|c|}{ The case of the Langmuir isotherm model } \\
\hline 160 & $0.0184 \pm 0.0029$ & $-0.7905 \pm 0.2778$ & $87.5047 \pm 6.4788$ & 0.9727 \\
\hline 200 & $0.0030 \pm 0.0022$ & $0.9091 \pm 0.2664$ & $86.8949 \pm 6.8402$ & 0.9852 \\
\hline 240 & $0.0102 \pm 0.0040$ & $0.6964 \pm 0.5142$ & $87.4997 \pm 15.7820$ & 0.9780 \\
\hline
\end{tabular}

adsorption, while $R_{\mathrm{L}}>1$ represents an unfavorable adsorption and $R_{\mathrm{L}}=1$ represents the linear adsorption. Moreover, the adsorption operation is irreversible if $R_{\mathrm{L}}=0$ (Gupta and Babu 2009).

The parameters of the other seven presented isotherm models were estimated by NLRA. The fitting of these models to the present data was less satisfactory than the fitting of the Freundlich model for both treated and untreated materials (Table 2).

Kinetics of adsorption

\section{Kinetic models' equations}

The kinetics of adsorption of $\mathrm{Cr}(\mathrm{VI})$ on various materials has been extensively studied using four kinetic equations. The widely used Lagergren equation (Lagergren 1898) is shown below:

$q-q_{t}=q \cdot e^{-k \cdot t}$

where $q$ and $q_{t}$ are the amounts of $\mathrm{Cr}(\mathrm{VI})$ adsorbed per unit mass of the adsorbent (in $\mathrm{mg} \mathrm{g}^{-1}$ ) at equilibrium time $(t \rightarrow \infty)$ and adsorption time $t$, respectively, while $k$ is the pseudo-first order rate constant for the adsorption process (in $\left.\min ^{-1}\right)$. Furthermore, $q=\left(C_{0}-C_{\mathrm{e}}\right) V / m$ and $q_{t}=$ $\left(C_{0}-C\right) V / m(18)$ where $C, C_{0}, C_{\mathrm{e}}$ are the concentrations of $\mathrm{Cr}(\mathrm{VI})$ in the bulk solution at time $t, 0$, and $\infty$, respectively, while $m$ is the weight of the adsorbent used (in $\mathrm{g}$ ), and $V$ is the solution volume (in $\mathrm{mL}$ ). Further modification of Eq. (18) in logarithmic form gives

$\ln \left(q-q_{t}\right)=\ln q-k \cdot t$

The $\kappa$-order kinetic model is

$d q / d t=k_{\kappa}\left(q-q_{t}\right)^{\kappa}$

Solving this differential Eq. for $\kappa \neq 1$, we obtain:

$q_{t}=q-\left[q^{1-\kappa}+(\kappa-1) k_{\kappa} t\right]^{1 /(1-\kappa)}$
The commonly used second-order kinetic model (Ho et al. 2000) is as follows:

$q_{t}=q-\left[q^{-1}+k_{2} t\right]^{-1}$ or $q_{t}=q-\frac{1}{\frac{1}{q}+k_{2} t}$

The possibility of intra-particle diffusion was explored using the intra-particle diffusion model (Weber and Morris 1963):

$q_{t}=c+k_{\mathrm{p}} \cdot \sqrt{t}$

where $q_{t}$ is the amount of $\mathrm{Cr}(\mathrm{VI})$ adsorbed at time $t, c$ is a constant $\left(\mathrm{mg} \mathrm{g}^{-1}\right)$, and $k_{\mathrm{p}}$ is the intra-particle diffusion rate constant in $\mathrm{mg} \mathrm{g}^{-1} \min ^{-0.5}$.

\section{Kinetic results and discussion}

The plots of $\ln \left(q-q_{t}\right)$ vs. $t$ for all Cr(VI) adsorbent systems were found to be linear, indicating the possibility of first-order nature of the adsorption process.

The Lagergren plots, as affected by the $\mathrm{Cr}(\mathrm{VI})$ initial concentration $C_{0}\left(\mathrm{mg} \mathrm{L}^{-1}\right)$, are shown in Fig. 3a. The maximum adsorbed amount of $\mathrm{Cr}(\mathrm{VI}) q$ (in $\mathrm{mg} \mathrm{g}^{-1}$ ) vs. the initial concentration $C_{0}$ (in $\mathrm{mg} \mathrm{L}^{-1}$ ) was found herein to follow the equation given below:

$q=0.0973 C_{0}+0.1588$

with $R^{2}=0.9593$. The adsorption temperature was $23{ }^{\circ} \mathrm{C}$, the $\mathrm{pH}=2.0$, and the solid to liquid ratio $m / V=4 \mathrm{~g}$ sawdust per $\mathrm{L}$ of solution. The $k$-values, as affected by $C_{0}$, were $0.013 \pm 0.002 \mathrm{~min}^{-1}$.

The Lagergren plots as affected by the solid/liquid ratio $m / V$ (in $\mathrm{g} \mathrm{L}^{-1}$ ) are shown in Fig. 3b. The $\%$ removal of $\mathrm{Cr}(\mathrm{VI}) r=q /\left(C_{0} \cdot V\right)$ vs. solid/liquid ratio was equal to

$r=q /\left(C_{0} \cdot V\right)=-0.0833(m / V)+0.1558$

with $R^{2}=0.9663$. The adsorption temperature was $23{ }^{\circ} \mathrm{C}$, the $\mathrm{Cr}(\mathrm{VI})$ initial concentration $C_{0}=5.0 \mathrm{mg} \mathrm{L}^{-1}$, and the $\mathrm{pH}=2.0$. In this case, the $k$-values were found to follow the equation given below: 

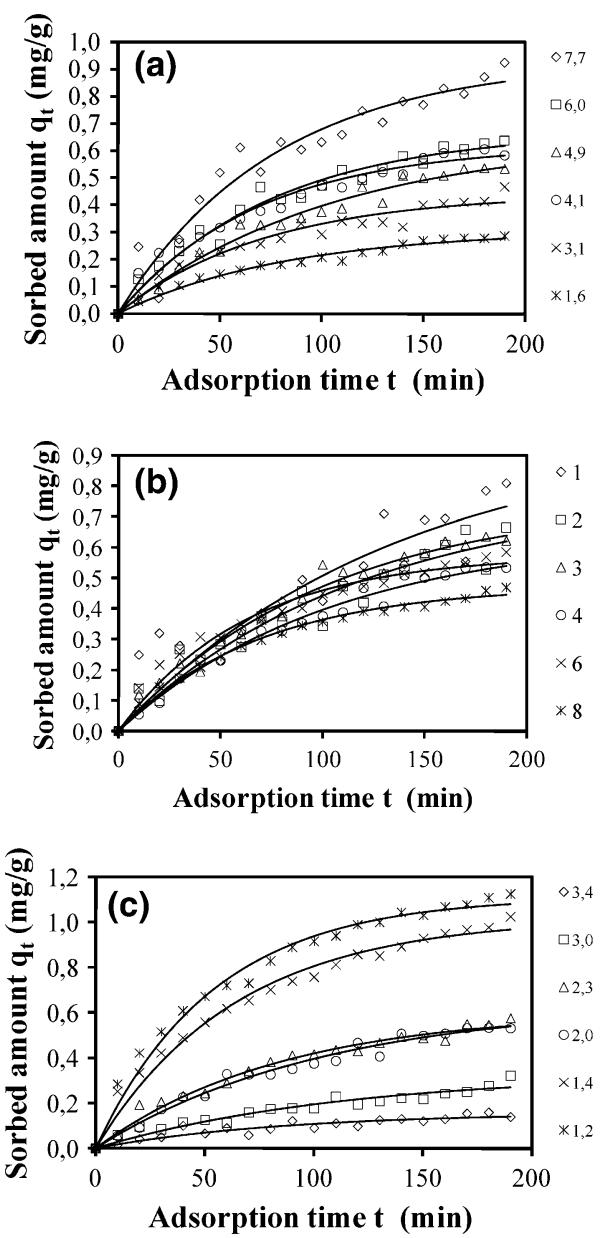

Fig. 3 Lagergren curves of $\mathrm{Cr}(\mathrm{VI})$ adsorption on pine sawdust as affected by a $\mathrm{Cr}(\mathrm{VI})$ initial concentration, b solid/liquid ratio $\mathrm{m} / \mathrm{V}$ and c $\mathrm{pH}$

$k=0.0012(m / V)+0.0061$

with coefficient of determination $R^{2}=0.8232$. The $k$-value range was $0.011 \pm 0.003 \mathrm{~min}^{-1}$.

The effect of the $\mathrm{pH}$ of the $\mathrm{Cr}(\mathrm{VI})$ solution on the amount of $\mathrm{Cr}(\mathrm{VI})$ adsorbed was studied by varying the initial $\mathrm{pH}$ under constant process parameters. The adsorption was negligible for $\mathrm{pH}=7.8$ or higher. In Fig. $3 \mathrm{c}$ the adsorption of $\mathrm{Cr}(\mathrm{VI})$ as affected by $\mathrm{pH}$ is presented. The \% removal of $\mathrm{Cr}(\mathrm{VI}) r$ was according to the following equation:

$r=q /\left(C_{0} \cdot V\right)=-0.3617 p H+1.3418$

with $R^{2}=0.9787$. The adsorption temperature was $23{ }^{\circ} \mathrm{C}$, the $\mathrm{Cr}(\mathrm{VI})$ initial concentration $C_{0}=5.0 \mathrm{mg} \mathrm{L}^{-1}$, the solid to liquid ratio $m / V=4 \mathrm{~g}$ sawdust/L solution, and $\mathrm{pH}=$ $1.2-3.4$. The $k$-value range was $0.013 \pm 0.004 \mathrm{~min}^{-1}$.

The first-order adsorption kinetics for untreated and pretreated sawdust is presented in Fig. 4a as regards the effect of the preheating time periods (i.e., zero isothermal autohydrolysis time periods) and in Fig. 5a for $50 \mathrm{~min}$
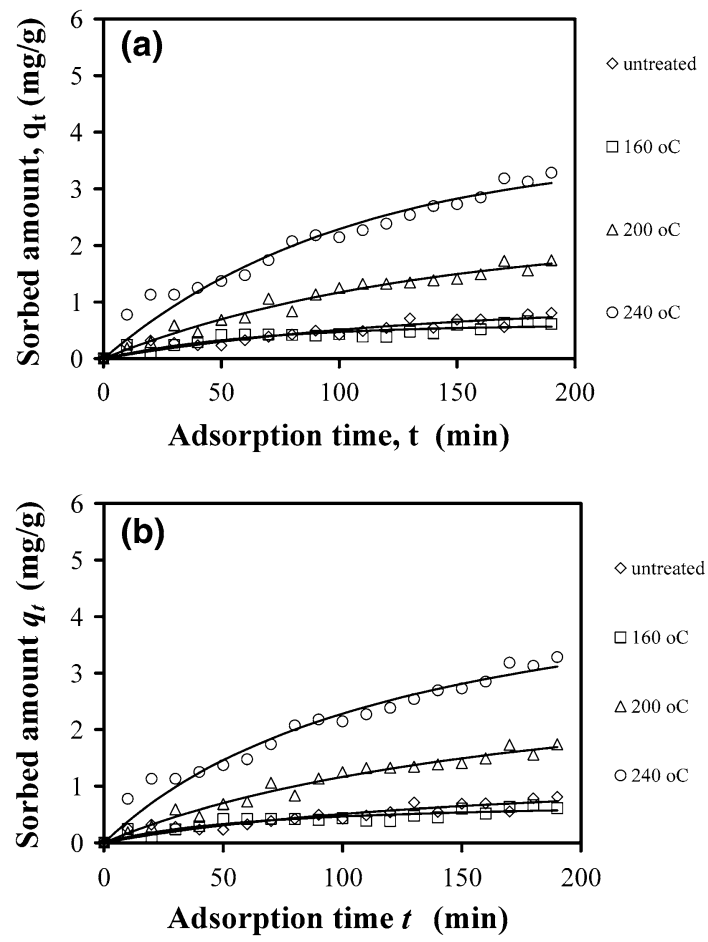

Fig. 4 a Lagergren curves and b second-order curves of $\mathrm{Cr}(\mathrm{VI})$ adsorption on untreated and autohydrolyzed (at 160, 200 and $240{ }^{\circ} \mathrm{C}$ for $0 \mathrm{~min}$ ) pine sawdust, showing the effect of preheating
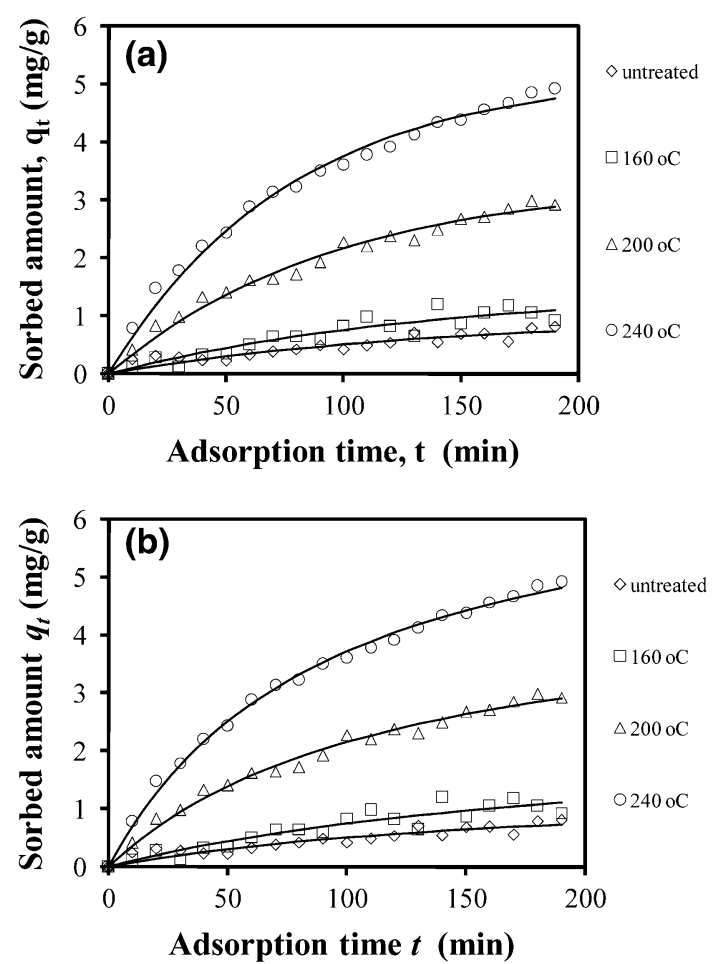

Fig. 5 a Lagergren curves and b second-order curves of $\mathrm{Cr}(\mathrm{VI})$ adsorption on untreated and autohydrolyzed (at 160, 200 and $240{ }^{\circ} \mathrm{C}$ for $50 \mathrm{~min}$ ) pine sawdust 
isothermal autohydrolysis time periods. The preheating periods were 42,62 , and $80 \mathrm{~min}$ for autohydrolysis temperatures 160,200 , and $240{ }^{\circ} \mathrm{C}$, respectively. Adsorption was significantly enhanced for preheating at 200 and $240{ }^{\circ} \mathrm{C}$ while the effect of preheating at $160{ }^{\circ} \mathrm{C}$ was negligible (Fig. 4a). The NLRA estimates of the first-order rate constants $k$ were $0.0074-0.0129 \mathrm{~min}^{-1}\left(0.0074 \mathrm{~min}^{-1}\right.$ for the untreated sawdust and $0.0129 \mathrm{~min}^{-1}$ for the most severe pretreated sawdust) and the SEE-values were 0.089-0.133. All SEE-values were found low, indicating the high applicability of this kinetic equation to the adsorption of $\mathrm{Cr}(\mathrm{VI})$ on pine sawdust.

The second-order kinetics is presented in Figs. $4 \mathrm{~b}$ and $5 \mathrm{~b}$ for $\mathrm{Cr}(\mathrm{VI})$ for untreated and pretreated pine sawdust. The NLRA-estimated values of the second-order rate constants $k_{2}$ were $0.00151-0.00387 \mathrm{~min}^{-1}$ and the SEE-values were 0.088-0.127. All SEE-values were found to be somewhat lower than those of the first-order kinetic model, indicating the marginally higher applicability of the secondorder kinetic equation to the adsorption of $\mathrm{Cr}(\mathrm{VI})$ on pine sawdust.
The $k$-values of the first-order kinetic model were significantly increased by the autohydrolysis pretreatment of pine sawdust, whereas the $k$-values of the second-order kinetic model were not significantly increased by autohydrolysis. However, the adsorption rate $\mathrm{d} q / \mathrm{d} t$ is significantly enhanced for both kinetic models due to the increase of the $\left(q-q_{t}\right)$ difference (Figs. 4, 5).

On the other hand, the order of the kinetic model was found to be $\kappa=2.11$ for the untreated and $\kappa=1.98$ -2.01 for the pretreated pine sawdust at various conditions.

Finally, the NLRA-estimated values of the intra-particle diffusion model rate constants $k_{p}$ were $0.0511-0.3596$ $\mathrm{mg} \mathrm{g}^{-1} \min ^{-0.5}(0.0511$ for the untreated and 0.3596 for the most severe pretreated sawdust) and the SEE values were 0.079-0.148.

\section{Desorption and reusability}

The $\mathrm{Cr}(\mathrm{VI})$ saturated adsorbent is not safe for the disposal due to stringent environmental constraints. The regeneration and reuse of adsorbent is important so as to reduce the

Table 4 Freundlich and Langmuir isotherms parameters of $\mathrm{Cr}(\mathrm{VI})$ adsorption on various adsorbents

\begin{tabular}{|c|c|c|c|c|c|c|c|}
\hline \multirow[t]{2}{*}{ Materials } & \multicolumn{2}{|l|}{ Freundlich } & \multicolumn{2}{|l|}{ Langmuir } & \multirow[t]{2}{*}{$\mathrm{pH}$} & \multirow[t]{2}{*}{$T\left({ }^{\circ} \mathrm{C}\right)$} & \multirow[t]{2}{*}{ Reference } \\
\hline & $\begin{array}{l}K_{\mathrm{F}}\left[\left(\mathrm{mg} \mathrm{g}^{-1}\right)(\mathrm{L}\right. \\
\left.\left.\mathrm{mg}^{-1}\right)^{1 / n}\right]\end{array}$ & $n$ & $q_{\mathrm{m}}\left(\mathrm{mg} \mathrm{g}^{-1}\right)$ & $\begin{array}{l}K_{\mathrm{L}}(\mathrm{L} \\
\left.\mathrm{mg}^{-1}\right)\end{array}$ & & & \\
\hline Almond shell & 0.153 & 2.86 & 0.046 & 0.580 & 3.5 & 25 & Pehlivan and Altun (2008) \\
\hline Almond shell & 0.6134 & 1.661 & 22.05 & 0.053 & 4 & - & Agarwal et al. (2006) \\
\hline Coir pith & 0.159 & 1.84 & - & - & 3 & - & Sumathi et al. (2005) \\
\hline Cotton stalk peel & 2.9 & 2.99 & 13.8 & 0.014 & 5.12 & 20 & Xu et al. (2011) \\
\hline Cotton stalk peel (amine-cross linked) & 0.36 & 3.74 & 117.9 & 0.024 & 5.12 & 20 & Xu et al. (2011) \\
\hline Ground nut shell & 0.3239 & 1.146 & 5.88 & 0.057 & 4 & - & Agarwal et al. (2006) \\
\hline Hazelnut shell & 0.386 & 2.83 & 0.086 & 4.423 & 3.5 & 25 & Pehlivan and Altun (2008) \\
\hline $\begin{array}{l}\text { Mushroom (spent, modified by cationic } \\
\text { surfactant) }\end{array}$ & 4.017 & 2.168 & 43.86 & 0.03176 & 3 & 25 & Jing et al. (2011) \\
\hline Oak bark chars & 1.332 & 2.32 & 7.515 & 0.149 & 2 & 25 & Mohan et al. (2011) \\
\hline Oil palm fibre & 71.285 & 34.542 & 22.73 & 0.1807 & 1.5 & 28 & Isa et al. (2008) \\
\hline Rice husk & 0.056 & 1.566 & - & - & 3 & - & Sumathi et al. (2005) \\
\hline Rice husk carbon & 21.61 & 5.36 & 48.31 & 0.27 & 2 & 25 & Bansal et al. (2009) \\
\hline Sawdust & 1.481 & 26.74 & - & - & 3 & - & Sumathi et al. (2005) \\
\hline Sawdust & 16.66 & 0.209 & 41.52 & 0.438 & 1 & 30 & Gupta and Babu (2009) \\
\hline Sawdust (carbonized) & 0.96 & 7.75 & 53.48 & 0.56 & 2 & 25 & Bansal et al. (2009) \\
\hline Sawdust & 2.276 & 1.945 & 87.4 & 0.00348 & 2 & 23 & In this work \\
\hline $\begin{array}{l}\text { Sawdust (autohydrolyzed, } 240{ }^{\circ} \mathrm{C} \text {, } \\
50 \mathrm{~min} \text { ) }\end{array}$ & 8.928 & 4.776 & 345.9 & 0.00696 & 2 & 23 & In this work \\
\hline Tamarindus indica seeds & 49.910 & 4.162 & 98.04 & 1.29 & 2 & - & Agarwal et al. (2006) \\
\hline Tea residue & 7.0129 & 1.845 & 29.76 & 0.27 & - & 25 & $\begin{array}{l}\text { Dizadji and Abootalebi } \\
\text { Anaraki (2011) }\end{array}$ \\
\hline Walnut hull & 45.60 & 6.87 & 98.13 & 0.1795 & 1 & 30 & Wang et al. (2009) \\
\hline Walnut shell & 0.244 & 3.36 & 0.076 & 2.982 & 3.5 & 25 & Pehlivan and Altun (2008) \\
\hline Walnut shell & 0.9866 & 2.277 & 2.28 & 1.286 & 4 & - & Agarwal et al. (2006) \\
\hline Wheat bran & 0.272 & 3.246 & 282.54 & 0.604 & 2 & 20 & Singh et al. (2009) \\
\hline
\end{tabular}


load on environment in terms of disposal of polluted adsorbent (Gupta and Babu 2009). Cr(VI) desorption from saturated untreated and pretreated sawdust using pure water was studied in the present work. Desorption efficiency was calculated using following equation:

$\begin{aligned} \text { Desorption_efficiency }= & \frac{\text { amount_of_Cr}(\mathrm{VI}) \_ \text {desorbed }}{\text { amount_of_Cr(VI)_sorbed }} \\ \times 100 & \text {. }\end{aligned}$

The results were $23.3-48.8 \% \mathrm{Cr}(\mathrm{VI})$ desorption for untreated pine sawdust and 5.8-17.6\% Cr(VI) desorption for autohydrolyzed pine sawdust batch experiments at $\mathrm{pH}=7.8$. These findings are comparable to some literature data (Jing et al. 2011). These desorption efficiency values limit the reusability of the pretreated material. On the other hand, it is reported that desorption of $\mathrm{Cr}(\mathrm{VI})$ is facilitated by increasing the solution $\mathrm{pH}$ (Singh et al. 2009). Moreover, desorption of $\mathrm{Cr}(\mathrm{VI})$ from sawdust using acid and base treatment exhibits higher desorption efficiency by more than $95 \%$ (Gupta and Babu 2009). In this case the material has high reusability.

Comparison with other biobased materials

Comparing the $\mathrm{Cr}(\mathrm{VI})$ adsorption capacities $K_{\mathrm{F}}$ and $q_{\mathrm{m}}$ of the autohydrolyzed and untreated pine sawdust with other agricultural or waste lignocellulosic-based adsorbents in literature (Table 4$)$, the autohydrolyzed $\left(240{ }^{\circ} \mathrm{C}, 50 \mathrm{~min}\right)$ pine sawdust exhibits the higher $q_{\mathrm{m}}=345.9 \mathrm{mg} \mathrm{g}^{-1}$.

Adsorption using activated carbon is considered to be one of the most efficient commercial methods for removing heavy metals from water/wastewater which is a major environmental problem. The process could be extremely expensive due to the high cost of activated carbon, especially when treating large amounts of water/wastewater containing heavy metals in low concentrations from small scale industries (Wang and Chen 2009).

Thereby, the $\mathrm{Cr}(\mathrm{VI})$ adsorption capacity of autohydrolyzed pine sawdust is quite satisfactory, rendering this lowcost material a suitable alternative of commercial activated carbons for the removal of chromium from water/wastewater effluents. Moreover, the pretreatment expenses can be covered by the produced sugars, raw materials for the bioethanol production industry. Evidently, this process of adsorbent modification, where a wasted material is used in the management of another waste, may be considered to take place within an 'Industrial Ecology' framework (Sidiras et al. 2011b).

The proposed herein material can be used at pilot or large-scale either in batch tanks or in packed bed columns for removing $\mathrm{Cr}(\mathrm{VI})$ from water and industrial wastewater.

\section{Conclusion}

The results presented herein indicate that the batch kinetics of $\mathrm{Cr}(\mathrm{VI})$ adsorption on autohydrolyzed pine sawdust was significantly enhanced, compared with those of the untreated material. The severity of autohydrolysis had a positive effect on the adsorptivity of the pine sawdust as determined using the EDS technique. The Freundlich and Langmuir adsorption capacity values of the autohydrolyzed sawdust were significantly increased by autohydrolysis pretreatment temperature and time. The material autohydrolyzed at $240{ }^{\circ} \mathrm{C}$ for $50 \mathrm{~min}$ exhibited the higher adsorption capacity as compared with other autohydrolysis conditions and materials presented in literature.

Acknowledgments This research has been co-financed by the European Union (European Social Fund-ESF) and Greek national funds through the Operational Program "Education and Lifelong Learning" of the National Strategic Reference Framework (NSRF)—Research Funding Program: THALIS-University of Piraeus-development of new material from waste biomass for hydrocarbons adsorption in aquatic environments (MIS 377356). In addition, support from National Centre for Scientific Research "Demokritos" is gratefully acknowledged. Moreover, the authors would like to thank the anonymous reviewers for their insightful suggestions to improve the initial manuscript.

\section{Nomenclature}

$A_{\mathrm{D}} \quad$ Dubinin-Radushkevich isotherm dimensionless constant

$a_{i} \quad$ Empirical parameters of Eqs. (15) and (16) $i=0$, 1,2

$A_{\mathrm{T}} \quad$ Temkin isotherm constant $\left(\mathrm{L} \mathrm{g}^{-1}\right)$

$B_{\mathrm{T}} \quad$ Temkin isotherm constant $\left(\mathrm{mg} \mathrm{g}^{-1}\right)$

$B_{\mathrm{D}} \quad$ Dubinin-Radushkevich isotherm constant

$b_{\mathrm{T}} \quad$ Temkin isotherm constant related to heat of sorption $\left(\mathrm{J} \mathrm{mol}^{-1}\right)$

$C \quad$ Concentrations of $\mathrm{Cr}(\mathrm{VI})$ in the bulk solution at time $t$

$c \quad$ Intercept of the intra-particle diffusion equation $\left(\mathrm{mg} \mathrm{g}^{-1}\right)$

$C_{0} \quad$ Initial $\mathrm{Cr}(\mathrm{VI})$ concentration $\left(\mathrm{mg} \mathrm{L}^{-1}\right)$

$C_{\mathrm{e}} \quad$ Equilibrium concentration of the adsorbate $(\mathrm{mg}$ $\mathrm{L}^{-1}$ ) for $t \rightarrow \infty$

$k \quad$ First-order rate constant for the batch adsorption process $\left(\mathrm{min}^{-1}\right)$

$k_{2} \quad$ Second-order rate constant for the batch adsorption process $\left(\mathrm{min}^{-1}\right)$

$k_{\kappa} \quad \kappa$-order rate constant for the batch adsorption process $\left(\min ^{-1}\right)$

$K_{\mathrm{F}} \quad$ Freundlich constant related to adsorption capacity $\left(\mathrm{mg} \mathrm{g}^{-1}\right)\left(\mathrm{L} \mathrm{mg}^{-1}\right)^{1 / n}$

$K_{\mathrm{L}} \quad$ Langmuir constant related to the energy of adsorption $\left(\mathrm{L} \mathrm{mg}^{-1}\right)$

$k_{\mathrm{p}} \quad$ Intra-particle diffusion rate constant $\left(\mathrm{mg} \mathrm{g}^{-1}\right.$ $\min ^{-0.5}$ ) 
$m \quad$ Adsorbent mass (g)

$n$ Inverse of the slope of the linearized (logarithmic) Freundlich isotherm, is related to adsorption intensity

NLRA Non-linear regression analysis

$q \quad$ Amount adsorbed per unit mass of the adsorbent for $t \rightarrow \infty\left(\mathrm{mg} \mathrm{g}^{-1}\right)$

$q_{\mathrm{D}} \quad$ Dubinin-Radushkevich isotherm constant $\left(\mathrm{mg} \mathrm{g}^{-1}\right)$

$q_{\mathrm{m}} \quad$ Langmuir constant related to the amount of $\mathrm{Cr}(\mathrm{VI})$ adsorbed $\left(\mathrm{mg} \mathrm{g}^{-1}\right)$ when saturation is attained

$q_{\mathrm{t}} \quad$ Amount of $\mathrm{Cr}(\mathrm{VI})$ adsorbed per unit mass of the adsorbent $\left(\mathrm{mg} \mathrm{g}^{-1}\right)$ at time $t$

$r \quad$ The \% removal of $\mathrm{Cr}(\mathrm{VI})$

$R \quad$ The gas constant $\left(0.008314 \mathrm{~kJ} \mathrm{~mol}^{-1} \mathrm{~K}^{-1}\right)$

$R^{2} \quad$ Coefficient of determination

$R_{\mathrm{L}} \quad$ Dimensionless constant called 'equilibrium parameter' or 'separation factor' expressing the essential characteristics of the Langmuir isotherm

$s \quad$ Constant of the UNILAN isotherm model

SEE Standard error of estimate

$t \quad$ Adsorption time ( $\mathrm{min})$

$T \quad$ Adsorption temperature (K)

$t_{\mathrm{a}} \quad$ Autohydrolysis time (min), $t_{\mathrm{a}}=t_{\mathrm{p}}+t_{\mathrm{ai}}$

$T_{\mathrm{a}} \quad$ Autohydrolysis temperature (K)

$t_{a i} \quad$ Autohydrolysis isothermal time (min)

$t_{\mathrm{p}} \quad$ Autohydrolysis preheating time (min)

$T_{\theta} \quad$ Adsorption temperature $\left({ }^{\circ} \mathrm{C}\right)$

$T_{\theta \mathrm{a}} \quad$ Autohydrolysis temperature $\left({ }^{\circ} \mathrm{C}\right)$

$V \quad$ Volume of $\mathrm{Cr}(\mathrm{VI})$ solution (L)

$\kappa \quad$ Order of the adsorption kinetic model

$\lambda \quad$ Spectrophotometer wavelength $(\mathrm{nm})$

\section{References}

Agarwal GS, Bhuptawat HK, Chaudhari S (2006) Biosorption of aqueous chromium(VI) by Tamarindus indica seeds. Bioresour Technol 97:949-956. doi:10.1016/j.biortech.2005.04.030

Aliabadi M, Morshedzadeh K, Soheyli H (2006) Removal of hexavalent chromium from aqueous solution by lignocellulosic solid wastes. Int J Environ Sci Tech 3:321-325

Bansal M, Singh D, Garg VK (2009) A comparative study for the removal of hexavalent chromium from aqueous solution by agriculture wastes' carbons. J Hazard Mater 171:83-92. doi: 10.1016/j.jhazmat.2009.05.124

Baral SS, Das SN, Rath P (2006) Hexavalent chromium removal from aqueous solution by adsorption on treated sawdust. Biochem Eng J 31:216-222. doi:10.1016/j.bej.2006.08.003

Baral S, Das S, Roy Chaudhury G, Swamy Y, Rath P (2008) Adsorption of $\mathrm{Cr}(\mathrm{VI})$ using thermally activated weed Salvinia cucullata. Chem Eng J 139:245-255. doi:10.1016/j.cej.2007. 07.090
Barwick M, Maher W (2003) Biotransference and biomagnification of selenium copper, cadmium, zinc, arsenic and lead in a temperate seagrass ecosystem from Lake Macquarie Estuary, NSW, Australia. Mar Environ Res 56:471-502. doi:10.1016/S01411136(03)00028-X

Blázquez G, Hernáinz F, Calero M, Martín-Lara MA, Tenorio G (2009) The effect of $\mathrm{pH}$ on the biosorption of $\mathrm{Cr}(\mathrm{III})$ and $\mathrm{Cr}(\mathrm{VI})$ with olive stone. Chem Eng J 148:473-479. doi:10.1016/j.cej. 2008.09.026

Chand R, Watari T, Inoue K, Torikai T, Yada M (2009) Evaluation of wheat straw and barley straw carbon for $\mathrm{Cr}(\mathrm{VI})$ adsorption. Sep Purif Technol 65:331-336. doi:10.1016/j.seppur.2008.11.002

Chern JM, Wu CY (2001) Desorption of dye from activated carbon beds: Effects of temperature, $\mathrm{pH}$, and alcohol. Wat Res 35:4159-4165. doi:10.1016/S0043-1354(01)00127-0

Dean S, Tobin J (1999) Uptake of chromium cations and anions by milled peat. Resour Conserv Recycl 27:151-156. doi:10.1016/ S0921-3449(98)00095-0

Dizadji N, Abootalebi Anaraki N (2011) Adsorption of chromium and copper in aqueous solutions using tea residue. Int J Environ Sci Tech 8:631-638. doi:10.1016/S0141-1136(03)00028-X

Dubinin M, Radushkevich L (1947) Equation of the characteristic curve of activated charcoal. Chem. Zentr 1:875-890

Economou-Eliopoulos M, Megremi I, Vasilatos Ch (2011) Factors controlling the heterogeneous distribution of $\mathrm{Cr}(\mathrm{VI})$ in soil, plants and groundwater: Evidence from the Assopos basin, Greece. Chemie der Erde-Geochem 71:39-52. doi:10.1016/ j.chemer.2011.01.001

Freundlich HMF (1906) Über die adsorption in lösungen. Z Phys Chem 57:385-471

Gupta S, Babu BV (2009) Removal of toxic metal Cr(VI) from aqueous solutions using sawdust as adsorbent: Equilibrium, kinetics and regeneration studies. Chem Eng J 150:352-365. doi: 10.1016/j.cej.2009.01.013

Gupta VK, Carrott PJM, Ribeiro-Carrott MML, Suhas (2009) Lowcost adsorbents: growing approach to wastewater treatment-a review. Crit Rev Environ Sci Tec 39:783-842. doi:10.1080/ 10643380801977610

Ho YS, Ng JCY, McKay G (2000) Kinetics of pollutants sorption by biosorbents: review. Sep Purif Methods 29:189-232

Isa MH, Ibrahim N, Aziz HA, Adlan MN, Sabiani NHM, Zinatizadeh AAL, Kutty SRM (2008) Removal of chromium (VI) from aqueous solution using treated oil palm fibre. J Hazard Mater 152:662-668. doi:10.1016/j.jhazmat.2007.07.033

Jing X, Cao Y, Zhang X, Wang D, Wu X, Xu H (2011) Biosorption of chromium (VI) from simulated using cationic surfactant modified spent mushroom. Desalination 269:120-127. doi:10.1016/ j.desal.2010.10.050

Lagergren S (1898) Zur theorie der sogenannten adsorption gelöster stoffe. Kungliga Svenska Vetenskapsakademiens, Handlingar 24:1-39

Langmuir I (1916) The constitution and fundamental properties of solids and liquids. J Am Chem Soc 38:2221-2295. doi:10.1021/ ja02268a002

Marshall WE, Wartelle LH (2004) An anion exchange resin from soybean hulls. J Chem Technol Biotechnol 79:1286. doi: $10.1002 /$ jctb. 1126

Mohan D, Rajput S, Singh VK, Steele PH, Pittman CU (2011) Modeling and evaluation of chromium remediation from water using low cost bio-char, a green adsorbent. J Hazard Mater 188:319-333. doi:10.1016/j.jhazmat.2011.01.127

Mosier N, Wyman C, Dale B, Elander R, Lee YY, Holtzapple M, Ladisch M (2005) Features of promising technologies for pretreatment of lignocellulosic biomass. Bioresource Technol 96:673-686. doi:10.1016/j.biortech.2004.06.025 
Nabarlatz D, Ebringerová A, Montané D (2007) Autohydrolysis of agricultural by-products for the production of xylo-oligosaccharides. Carbohyd Polym 69:20-28. doi:10.1016/j.carbpol.2006. 08.020

Nameni M, Alavi Moghadam MR, Arami M (2008) Adsorption of hexavalent chromium from aqueous solutions by wheat bran. Int J Environ Sci Tech 5:161-168

Oliveira EA, Montanher SF, Andrade AD, Nobrega JA, Rollemberg MC (2005) Equilibrium studies for the sorption of chromium and nickel from aqueous solutions using raw rice bran. Proc Biochem 40:3485-3490. doi:10.1016/j.procbio.2005.02.026

Park D, Yun YS, Jo JH, Park JM (2005) Mechanism of hexavalent chromium removal by dead fungal biomass of Aspergillus niger. Wat Res 39:533-540. doi:10.1016/j.watres.2004.11.002

Pehlivan E, Altun T (2008) Biosorption of chromium (VI) ion from aqueous solution using walnut, hazelnut and almond shell. J Hazard Mater 155:378-384. doi:10.1016/j.jhazmat.2007. 11.071

Radke CJ, Prausnitz JM (1972) Adsorption of organic solutes from dilute aqueous solution on activated carbon. Ind Eng Chem Fundam 11:445-451. doi:10.1021/1160044a003

Saeman JF, Bubl JF, Harris EE (1945) Quantitative saccharification of wood and cellulose. Ind Eng Chem Anal Ed 17:35-37. doi: 10.1021/i560137a008

Sarin V, Pant KK (2006) Removal of chromium from industrial waste by using eucalyptus bark. Bioresour Technol 7:15-20. doi: 10.1016/j.biortech.2005.02.010

Sharma DC, Forster CF (1996) A comparison of the sorbtive characteristics of leaf mould and activated carbon columns for the removal of hexavalent chromium. Process Biochem 31: 213-218. doi:10.1016/0032-9592(95)00049-6

Sidiras D, Batzias F, Schroeder E, Ranjan R, Tsapatsis M (2011a) Dye adsorption on autohydrolyzed pine sawdust in batch and fixed-bed systems. Chem Eng J 171:883-896. doi:10.1016/j. cej.2011.04.029

Sidiras D, Batzias F, Ranjan R, Tsapatsis M (2011b) Simulation and optimization of batch autohydrolysis of wheat straw to monosaccharides and ligosaccharides. Bioresour Technol 102:10486-

10492. doi:10.1016/j.biortech.2011.08.059

Singh KK, Hasan SH, Talat M, Singh VK, Gangwar SK (2009) Removal of $\mathrm{Cr}(\mathrm{VI})$ from aqueous solutions using wheat bran. Chem Eng J 151:113-121. doi:10.1016/j.cej.2009.02.003

Sips R (1948) Structure of a catalyst surface. J Chem Phys 16:490-495. doi:10.1063/1.1746922

Sumathi KMS, Mahimairaja S, Naidu R (2005) Use of low-cost biological wastes and vermiculite for removal of chromium from tannery effluent. Bioresour Technol 96:309-316. doi:10.1016/j. biortech.2004.04.015

Tappi Standards (1997) Tappi tests methods, T222 om-88, Atlanta

Temkin MJ, Pyzhev V (1940) Recent modification to Langmuir isotherms. Acta Physiochim, URSS 12:217-222

Toth J (2000) Calculation of the BET-compatible surface area from any Type I isotherms measured above the critical temperature. J Colloid Interface Sci 225:378-383. doi:10.1006/jcis.2000.6723

Vinodhini V, Das N (2010) Relevant approach to assess the performance of sawdust as adsorbent of chromium (VI) ions from aqueous solutions. Int J Environ Sci Tech 7:85-92

Wang J, Chen C (2009) Biosorbents for heavy metals removal and their future. Biotechnol Adv 27:195-226

Wang XS, Li ZZ, Tao SR (2009) Removal of chromium (VI) from aqueous solution using walnut hull. $\mathrm{J}$ Environ Manag 90:721-729. doi:10.1016/j.jenvman.2008.01.011

Weber WJ, Morris JC (1963) Kinetics of adsorption on carbon from solution. J Sanit Eng Div Am Soc Civ Eng 89:31-60

Xu X, Gao BY, Tang X, Yue QY, Zhong QQ, Li Q (2011) Characteristics of cellulosic amine-crosslinked copolymer and its sorption properties for $\mathrm{Cr}(\mathrm{VI})$ from aqueous solutions. J Hazard Mater 189:420-426. doi:10.1016/j.jhazmat.2011.02.056

Zvinowanda CM, Okonkwo JO, Shabalala PN, Agyei NM (2009) A novel adsorbent for heavy metal remediation in aqueous environments. Int J Environ Sci Tech 6:425-434 